\title{
Cerrahi Kliniklerinde Yatan Hastaların Anksiyete ve Depresyon Düzeylerinin Belirlenmesi*
}

\section{Determination of Level of Anxiety and Depression of Patients Hospitalized in Surgery Clinics}

Fadime Gök ${ }^{1}$ [D, Filiz Kabu Hergül ${ }^{1}$ (D)

\footnotetext{
* Bu çalışma 10-12 Temmuz 2017 tarihinde Berlin'de "23rd World Nursing and Healthcare Conference"nda sözel bildiri olarak sunulmustur.

1 Pamukkale Üniversitesi, Sağlık Bilimleri Fakültesi, Hemșirelik Bölümü, Denizli, Türkiye
}

ORCID: F.G. 0000-0003-0415-4229;

F.K.H. 0000-0002-9171-7546

Corresponding author/Sorumlu yazar: Filiz Kabu Hergül,

Pamukkale Üniversitesi, Sağlık Bilimleri Fakültesi, Hemşirelik Bölümü, Denizli, Türkiye

E-mail: filizhergul35@gmail.com

Submitted/Geliş tarihi: 03.07.2020 First Revision Received/İlk revizyon: 28.07.2020 Last Revision Received/Son revizyon: 09.10.2020 Accepted/Kabul Tarihi: 19.10.2020

Citation/Atıf: Gok F, Kabu Hergul F. Determination of level of anxiety and depression of patients hospitalized in surgery clinics. Sağlık Bilimlerinde İleri Araştırmalar Dergisi 2020; 3(3): 195-206.

https://doi.org/10.26650/JARHS2020-763519
ÖZ

Amaç: Tanımlayıcı ve kesitsel tipteki bu araştırmanın amacı, cerrahi kliniklerinde yatan hastaların anksiyete ve depresyon düzeylerinin belirlenmesi ve ilişkili olabilecek faktörlerin incelenmesidir.

Gereç ve Yöntem: Çalıșmanın başlangıcında evren bilinmediği için örneklem sayısı "evreni bilinmeyen örneklem formülü” ile hesaplandı. Çalışmanın örneklemi bu yöntemle 740 hasta olarak hesaplanmış olup, çalışmanın planlandığı sürenin (Şubat 2015 - Eylül 2015) sonuna kadar çalıșma sürdürüldü. Bu sürenin sonunda 774 hasta çalıșmaya dahil edildi. Veriler hastaların sosyo-demografik verilerinin yer aldığı "Tanıtıcı Özellikler Formu" ve "Hastane Anksiyete Depresyon Ölçeği” aracilığıyla toplandı. Verilerin değerlendirilmesinde ortalama, standart sapma, sayı, yüzde, Kruskal-Wallis, Independent- Sample T Testi ve One- Way ANOVA testi kullanıldı.

Bulgular: Hastaların en genci 18 , en büyügü 95 , ortalama $54,81 \pm 17,77$ yaşında olup, en az 1 en çok 150, Medyan:8,31, 1R:6 gündür hastanede yatmaktadır. Hastaların \%54,1'i erkek, \%50,3'ü ilkokul mezunu, \%35,3'ü ev hanımıdır. Hastaların Hastane Anksiyete

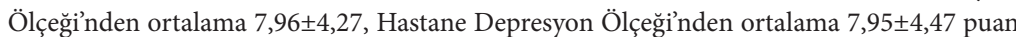
aldığı saptandı. İleri yaş grubunda olan, okur-yazar olmayan, hastanede uzun süre kalan, kronik hastalığı olan, hemşirelik bakımından memnun olmayan, ekonomik durumu kötü olan ve sosyal güvencesi olmayan hastaların hem anksiye düzeyleri, hem de depresyon düzeyleri daha yüksek olarak bulundu. Hastaların medeni durumları, yaşadığı yer, tedavi gördügü hastane/klinik, hastanede yatma ve ameliyat olma deneyimi, kanser tanısı alma durumu, ameliyat öncesi /sonrası dönem, sağlık personeli ile iletişim kurabilme, hastalığı hakkında bilgi alma, destek alma ve gereksinimlerinin karșılanması durumu ile anksiyete ve depresyon düzeyi puan ortalamaları arasında istatistiksel olarak anlamlı fark olmadığ saptandi $(\mathrm{p}>0.05)$.

Sonuç: Hastaların anksiyete puan ortalaması ölçek kesme puanının altında, depresyon puan ortalaması ise ölçek kesme puanının üstündedir. Sonuç olarak çalıșmamızda cerrahi hastaların depresyon açısından risk altında olduğu belirlenmiştir. Cerrahi birimlerde çalışan hemşirelerin bu riskleri göz önünde bulundurarak bakımlarını planlamaları ile hasta bakım kalitesinin artacağı düşünülmektedir.

Anahtar Kelimeler: Cerrahi hasta, depresyon, anksiyete, hemşirelik

\section{ABSTRACT}

Objective: The objective of this descriptive and cross-sectional study is the determination of level of anxiety and depression of the patients hospitalized in surgery clinics and the factors which may be associated.

Materials and Methods: The population was unknown at the beginning of the study and therefore the sample size was calculated to be 740 by using the "sample formula of unknown universe". The study continued until the end of the planned period (February 2015 - September 2015). By the end of this period, 774 patients were included in the study. The data were collected through the "Participant Information Form" containing the socio- 
demographic data of the patients and the "Hospital Anxiety Depression Scale". For evaluation of the data; mean, standard deviation, count, percentage, Kruskal-Wallis, Independent-Sample T test and One-Way ANOVA test were used.

Results: Of the patients, the youngest was 18 , the oldest was 95 and the mean age was $54.81 \pm 17.77$; they were hospitalized for at least 1 , at most 150, Median: $8.31,1 \mathrm{R}: 6$ days. Of the patients, $54.1 \%$ were male, $50.3 \%$ were primary school graduate and $35.3 \%$ were housewives. The patients were determined to score a mean of $7.96 \pm 4.27$ points on the Hospital Anxiety Scale and a mean of $7.95 \pm 4.47$ points on the Hospital Depression Scale. Both anxiety and depression levels were higher in patients of the advanced age group, who were illiterate, had been hospitalized for a long period, had a chronic disease, were unsatisfied with their nursing care, of poor economic status and without social security. There was no statistically significant difference between "Hospital Anxiety Depression Scale" mean scores ( $p>0.05)$ and patients' marital status, their place of residence, the hospital / clinic where they received treatment, their experience of hospitalization and surgery, their status of being diagnosed with cancer, their pre / post-operative period, their communication with healthcare personnel and getting information and getting support about the disease and meeting their needs. Conclusion: The mean anxiety score of the patients was below the cut-off score and the mean depression score was above the cut-off score. As a result, the study concluded that surgical patients were at risk for depression. The quality of patient care will increase when nurses working in surgical units plan their care by taking these risks into consideration.

Keywords: Surgical patient, depression, anxiety, nursing 


\section{GİRIŞ̧}

Hastalığa ilişkin tanı ne olursa olsun bireyi biyolojik, duygusal ve sosyal olarak olumsuz etkilemektedir $(1,2)$. Hastaneye yatan hastalar hastalıklarının yanı sıra tedavi sürecinde ve tedaviden sonraki süreçte birtakım zorluklar yaşayabilirler ve tüm bunların sonucunda endişeye kapılabilirler $(3,4)$. Hastalarda görülen anksiyete ve depresyonun nedeni, hastaneye olan uyum zorluğu ya da tanı ve tedavi sürecindeki belirsizlik olabilir (5). Bu süreçte hastalar tanıda belirsizlik, ölüm korkusu gibi stresli deneyimlerle karşılaşabilirler. Bunların dışında hastalar, beden imajında meydana gelen değişiklikler, öz bakım ihtiyaçlarını karşılamada yetersizlik nedeniyle psikolojik sıkıntılar yaşayabilmektedirler (4). Literatürde hastaların yaşadığı emosyonel problemlerin başında anksiyete ile depresyonun geldiği (2) ve prevalansının \%20 ile \%60 arasında değiştiği belirtilmektedir (4).

Cerrahi hastalarda tüm bunların yanı sıra ameliyat öncesi dönemde kontrol kaybı, ameliyat sonrası ağrı, ameliyat gününde belirsizlik ve ölüm korkusuyla sık karşılaşılmaktadır $(4,6)$. Ayrıca bu süreçte hastalar uyanamama, vücut bütünlügünün bozulması, organ ve doku kaybı, cinsel yaşamla ilgili problem yaşama gibi konularda da korku ve kaygılara sahip olabilirler $(6,7,8,9,10)$. Literatürde bu tür tepkilerin anksiyete, depresyon, geri çekilme ve inkar olarak karşımıza çıkabileceği vurgulanmakta (9) ve ameliyat sonrasinda daha fazla tıbbi komplikasyona neden olacağ 1 bildirilmektedir (6). Hastalar cerrahi travma nedeniyle korku ve endişe duyabilirler. Bu sebeplerle bu gruptaki hastalar, anksiyete ve depresyon açısindan risk altındadırlar $(3,7,11)$. Cerrahi hastalarda depresyon ve anksiyete özellikle ameliyat öncesi dönemde ve tedavisi zor kronik hastalıkları olan hastalarda yaygın olarak görülmektedir $(4,5,7,8)$.

Cerrahi hastalarda karşımıza çıkabilecek psikolojik bozuklukların ve fiziksel hastalıkların tanı ve tedavisini kolaylaştırmak için, risk faktörlerinin yanı sıra ilişkili faktörler de bilinmelidir (4). Hastanede kalış süresi uzayan hastaların, postoperatif komplikasyon gelişen hastaların, ailevi destek eksikliği olan hastaların ve yeniden işleme ihtiyaç duyulan hastaların anksiyete ve depresyon risklerinin diğer cerrahi hastalara göre daha yüksek olduğu belirtilmektedir (5). Anksiyete ve depresyonun ameliyat sürecindeki olumsuz etkilerinden dolayı, ameliyat öncesi dönemde kaygının kontrolü güvenli ve sorunsuz bir operasyon için çok önemlidir (9). Ameliyat öncesi ve ameliyat sürecinin yanı sıra anksiyete ve depresyon ameliyat sonrası süreçte de karşımıza çıkabilmektedir. Anksiyete ve depresyonun ameliyat sonrası dönemde işlev bozukluğuna neden olduğu, intihar oranını arttırdığı, yaşam kalitesini düşürdügü, hastalıkların iyileşmesini olumsuz yönde etkilediği, hastanede kalış süresini uzattığ ve sağlık hizmetleri maliyetlerini artırdığ 1 vurgulanmaktadır $(2,4,9)$. Tüm bunların yanı sıra hastalarda anksiyete ve depresyon oranları arttıkça cerrahi ile ilişkili risklerin arttığı ortaya konulmakta, anksiyete ve depresyonun taburculuk sonrası psikiyatrik bozukluklara neden olduğu, mortalite ve morbidite oranlarının arttırdığı belirtilmektedir $(2,3,5)$.

Hastalarda anksiyete ve depresyon düzeylerinin belirlenmesi kaliteli sağlık hizmeti verilebilmesi açısindan oldukça önemlidir $(1,3,12)$. Hastaların duygu durum bozuklukları ile ilgili risk düzeylerinin saptanması, anksiyete ve depresyon düzeylerinin tespitini kolaylaştırır (5). Bu nedenle sağlık profesyonellerinin anksiyete ve depresyon düzeylerinin belirlenmesi ve psikososyal yaklaşımlar konusunda yeterli donanıma sahip olması gerekmektedir $(1,3,12)$. Literatürde psikososyal yaklaşımların hastada güven duygusunu arttırdığı, fiziksel şikayetlerini azalttığı, hastalıkla ilişkili oluşan olumsuz duygusal tepkilerle baş etme yeteneğini ve yaşam kalitesini arttırdığg bildirilmektedir (1). Hastaların endişelerinin kaynaklarını tanımlamak ve bu konuyla ilgili rahatlamalarını sağlamak cerrahi süreçte oldukça önemlidir (9).

Cerrahi hastalarda anksiyete ve depresyonu tanıyabilmenin ameliyat öncesi ve ameliyat sonrası dönemde hasta bakım kalitesinin arttırılmasında önemli rol oynayacağı düşünülmektedir. Bu nedenle bu çalışma cerrahi kliniklerinde yatan hastaların anksiyete, depresyon düzeyleri ve etkileyen faktörlerin belirlenmesi amacıyla tanımlayıcı ve kesitsel olarak yapıldı.

Araştırma soruları;

- Cerrahi kliniklerinde yatan hastaların anksiyete ve depresyon görülme riski nedir? 
- Cerrahi kliniklerinde yatan hastaların anksiyete ve depresyon düzeylerini etkileyen faktörler nelerdir?

\section{GEREÇ VE YÖNTEM}

Çalışmanın başlangıcında evren bilinmediği için örneklem sayısı "evreni bilinmeyen örneklem formülü̉ ile hesaplandı. Çalışmanın örneklemi bu yöntemle 740 hasta olarak hesaplanmış olup, çalışmanın planlandığı sürenin (Şubat 2015 - Eylül 2015) sonuna kadar çalışma sürdürüldü. Bu sürenin sonunda 774 hasta çalışmaya dahil edildi. Gerekli yazılı izinler (etik kurul, kurum izni) alındıktan sonra gönüllülük ilkesine bağlı kalınarak, dahil olma kriterlerine uygun, araştırmaya katılmaya kabul eden tüm hastalar araştırma örneklemine dahil edildi.

Dahil Olma Kriterleri; Çalışmanın amacı ve yöntemi açıklandıktan sonra, çalışmaya katılmayı kabul eden, Türkçe konuşan, okuyup yazabilen, 18 yaş üzeri, görme, işitme engeli olmayan, rahat iletişim kurulabilen, aynı ortamda en az iki gün kalmış olan, anket formunu doldurabilen cerrahi kliniklerde yatmakta olan tüm hastalar çalışmaya dahil edildi $(\mathrm{n}=774)$.

Dışlama Kriterleri; 18 yaşını doldurmamış olan, okuma yazması olmayan, iletişimi engelleyecek herhangi bir fizyolojik ve psikiyatrik (görme-işitme) problemi olan, aynı ortamda iki günden az kalan ve anket formunu dolduramayacak olan hastalar çalışmadan dışlandı. Verilerin toplanmasında; Hastaların sosyo-demografik verilerinin yer aldığ 1 "Tanıtıc özellikler formu” ve "Hastane Anksiyete Depresyon Ölçeği” kullanıldı.

\section{I-Tanıtıcı özellikler formu (Ek I)}

Literatür bilgileri doğrultusunda hazırlanan, hastaların kişisel özelliklerini içeren 15 sorudan (yaş, cinsiyet, eğitim durumu vb.) oluşmaktadır.

\section{II- Hastane Anksiyete Depresyon Ölçeği (Ek II)}

Hastane Anksiyete Depresyon Ölçeği-HADÖ (Hospital Anxiety Depression Measure): Zigmond ve Snaith tarafindan hastada anksiyete ve depresyon yönünden riski belirlemek, düzeyini ve şiddet değişimini ölçmek için 1983'de geliştirilmiştir (Genel Cronbach alfa kat sayısı: 0.88, HADS-A scale, Cron- bach alfa: 0.90, HADS-D scale, Cronbach alfa: 0.79 dur) (13). Ölçeğin Türkiye'de geçerlilik güvenilirlik çalışması Aydemir ve arkadaşları tarafından 1997 yılında yapılmıştır (HAD-A scale, Cronbach alfa: 0.8525 HAD-D scale, Cronbach alfa: 0.7784'dür) (14). $\mathrm{Bu}$ çalışmada ise ölçeğin genel Cronbach alfa kat sayıs1: 0.853, HADS-A scale, Cronbach alfa katsayıs1: 0.764, HADS-D scale, Cronbach alfa katsayısı: 0.765 olarak bulundu. Bu ölçek bedensel hastalığı olan hastalar ve birinci basamak sağlık hizmetlerine başvuranlar için tanı koymak amaçlı değil anksiyete ve depresyonu kısa sürede tanılayıp risk grubunu belirlemek için kullanılır (14).

HADÖ toplam 14 maddeden oluşmaktadır. Tek sayılı maddeler anksiyete ve çift sayılı maddeler depresyonu ölçmektedir. Ölçek dörtlü Likert tipi bir değerlendirme aracıdır. Maddeler 0-3 arasında puanlanmaktadır. Ölçekte her maddenin puanlaması farklıdır. 1., 3., 5., 6., 8., 10., 11. ve 13. maddeler giderek azalan şiddet gösterirler ve puanlama 3, 2, 1, 0 biçimindedir Öte yandan, 2., 4., 7., 9., 12. ve 14. maddeler ise 0, 1, 2, 3 biçiminde puanlanırlar. Alt ölçeklerin toplam puanları bu madde puanlarının toplanması ile elde edilir. Anksiyete alt ölçeği için 1., 3., $5 .$, 7., 9., 11. ve 13. maddeler toplanırken; depresyon alt ölçeği için 2., 4., 6., 8., 10., 12. ve 14. maddelerin puanları toplanır. Hastaların her iki alt ölçekten alabilecekleri en düşük puan 0 , en yüksek puan 21'dir. HADÖ'nin Türkçe formunun kesme noktaları anksiyete alt ölçeği (HAD-A) için 10, depresyon alt ölçeği (HAD-D) için 7 olarak saptanmıştır (14). Bu puanların üzerinde puan elde edilen hastalar risk grubu olarak kabul edilebilir.

İstatistiksel Analiz ile İlgili Bilgi: Verilerin değerlendirilmesinde ortalama, standart sapma, sayı, yüzde, Kruskal-Wallis, Independent- Sample T Testi ve One- Way ANOVA testi kullanıldı.

\section{Çalışmadan Çıkarılma Kriterleri}

Anket formunu düzgün doldurmayan ya da araştırmaya dahil olma kriterlerine uygun olmadığı halde anket formunu dolduran hastalar çalışmadan ç1karild1. 


\section{Etik}

Araştırmanın uygulanabilmesi için Pamukkale Üniversitesi Tip Fakültesi (12.02.2015 tarih ve 60116787020/8537 sayılı) Etik Kurul Komitesinden ve araştırmanın yürütüldüğ̈ hastanelerden yazılı izin alındı. Hastalardan araştırmaya katılmaya isteklilik, gönüllülük ilkesine özen gösterilerek sözel onamları alındı.

\section{BULGULAR}

Çalışmaya dahil edilen hastaların tanıtıcı özellikleri tablo 1'de verildi. Hastaların en genci 18, en büyüğü 95 yaşında olup yaş ortalaması $54,81 \pm 17,77$ 'dir. Hasta- ların \%55,8'i ortalama 1-5 (en az 1 en çok 150, Medyan: 8.31, IR: 6) gündür hastanede yatmaktadır.

Hastaların tanıtıcı özelliklerine göre anksiyete ve depresyon düzeyi puan ortalamalarının dağılımı tablo 2'de verildi. Hastaların yaş, cinsiyet, öğrenim durumu, meslek, sağlık güvencesi, ekonomik durum, hastanede kalma süresi, ek hastalık varlığı, bilgi alma ve hemşirelik bakımından memnun olma durumlarına göre anksiyete ve depresyon puan ortalamaları arasında istatistiksel olarak anlamlı fark olduğu tespit edildi ( $\mathrm{p}<0,05$, Tablo 2). Buna karşın hastaların medeni durumları, yaşadığı yer, tedavi gördüğü hasta-

Tablo 1. Hastaların Tanıtıcı Özellikleri $(n=774)$

\begin{tabular}{|c|c|c|}
\hline Değişkenler & Sayı & $\%$ \\
\hline $\begin{array}{l}\text { Yaş grupları } \\
18-28 \text { yaş } \\
29-39 \text { yaş } \\
40-50 \text { yaş } \\
51-61 \text { yaş } \\
62-72 \text { yaş } \\
73 \text { yaş ve üzeri }\end{array}$ & $\begin{array}{c}81 \\
84 \\
140 \\
141 \\
193 \\
135\end{array}$ & $\begin{array}{l}10,5 \\
10,9 \\
18,1 \\
18,2 \\
24,9 \\
17,4\end{array}$ \\
\hline $\begin{array}{l}\text { Hastanede kalma süresi } \\
2-5 \text { gün } \\
6 \text {-11 gün } \\
\text { 12-16 gün } \\
\text { 17-21 gün } \\
22 \text { gün ve üzeri }\end{array}$ & $\begin{array}{c}432 \\
197 \\
76 \\
20 \\
49 \\
\end{array}$ & $\begin{array}{c}55,8 \\
25,5 \\
9,8 \\
2,6 \\
6,3 \\
\end{array}$ \\
\hline $\begin{array}{l}\text { Cinsiyet } \\
\text { Kadin } \\
\text { Erkek }\end{array}$ & $\begin{array}{l}355 \\
419\end{array}$ & $\begin{array}{l}45,9 \\
54,1\end{array}$ \\
\hline $\begin{array}{l}\text { Medeni durum } \\
\text { Evli } \\
\text { Bekar }\end{array}$ & $\begin{array}{l}610 \\
164\end{array}$ & $\begin{array}{l}78,8 \\
21,2\end{array}$ \\
\hline $\begin{array}{l}\text { Öğrenim durumu } \\
\text { Okur-yazar değil } \\
\text { Okur-yazar } \\
\text { İlköğretim } \\
\text { Ortaöğretim } \\
\text { Lise } \\
\text { Yüksekokul }\end{array}$ & $\begin{array}{c}22 \\
85 \\
389 \\
93 \\
109 \\
76\end{array}$ & $\begin{array}{c}2,8 \\
11,0 \\
50,3 \\
12,0 \\
14,1 \\
9,8\end{array}$ \\
\hline $\begin{array}{l}\text { Mesleği } \\
\text { Ev hanımı } \\
\text { İşçi } \\
\text { Emekli } \\
\text { Memur } \\
\text { Öğrenci } \\
\text { Serbest } \\
\text { Çiftçi }\end{array}$ & $\begin{array}{c}273 \\
141 \\
193 \\
51 \\
25 \\
57 \\
34\end{array}$ & $\begin{array}{r}35,3 \\
18,2 \\
24,9 \\
6,6 \\
3,2 \\
7,4 \\
4,4\end{array}$ \\
\hline $\begin{array}{l}\text { Sağlık güvencesi olma durumu } \\
\text { Var } \\
\text { Yok }\end{array}$ & $\begin{array}{c}726 \\
48\end{array}$ & $\begin{array}{c}93,8 \\
6,2 \\
\end{array}$ \\
\hline $\begin{array}{l}\text { Ekonomik durum } \\
\text { İyi } \\
\text { Orta } \\
\text { Kötü }\end{array}$ & $\begin{array}{c}86 \\
594 \\
94\end{array}$ & $\begin{array}{l}11,1 \\
76,7 \\
12,1\end{array}$ \\
\hline
\end{tabular}




\begin{tabular}{|c|c|c|}
\hline $\begin{array}{l}\text { En uzun yaşadığı yer } \\
\text { Köy } \\
\text { Kasaba } \\
\text { Ilçe } \\
\text { İl merkezi }\end{array}$ & $\begin{array}{c}192 \\
48 \\
237 \\
297\end{array}$ & $\begin{array}{r}24,8 \\
6,2 \\
30,6 \\
38,4 \\
\end{array}$ \\
\hline $\begin{array}{l}\text { Yattı̆̆ } \text { hastane } \\
\text { Pamukkale Üniversitesi Hastanesi } \\
\text { Denizli Devlet Hastanesi }\end{array}$ & $\begin{array}{l}575 \\
199\end{array}$ & $\begin{array}{l}74,3 \\
25,7\end{array}$ \\
\hline $\begin{array}{l}\text { Tedavi gördüğg̈ klinik } \\
\text { Genel Cerrahi } \\
\text { Ortopedi } \\
\text { Üroloji } \\
\text { Kalp Damar cerrahisi } \\
\text { Beyin Cerrahisi } \\
\text { Plastik Cerrahi } \\
\text { KBB }\end{array}$ & $\begin{array}{c}184 \\
146 \\
104 \\
110 \\
118 \\
52 \\
60\end{array}$ & $\begin{array}{c}23,8 \\
18,9 \\
13,4 \\
14,2 \\
15,2 \\
6,7 \\
7,8\end{array}$ \\
\hline $\begin{array}{l}\text { Tanı } \\
\text { Kanser cerrahisi } \\
\text { Kanser Dışı Cerrahi }\end{array}$ & $\begin{array}{l}109 \\
665\end{array}$ & $\begin{array}{l}14.1 \\
85.9\end{array}$ \\
\hline $\begin{array}{l}\text { Hastanede Yatma Deneyimi olma durumu } \\
\text { Var } \\
\text { Yok }\end{array}$ & $\begin{array}{l}560 \\
214 \\
\end{array}$ & $\begin{array}{l}72,4 \\
27,6 \\
\end{array}$ \\
\hline $\begin{array}{l}\text { Ameliyat deneyimi olma durumu } \\
\text { Var } \\
\text { Yok }\end{array}$ & $\begin{array}{l}490 \\
284 \\
\end{array}$ & $\begin{array}{l}63,3 \\
36,7\end{array}$ \\
\hline $\begin{array}{l}\text { Ameliyat olma durumu } \\
\text { Evet } \\
\text { Hayır }\end{array}$ & $\begin{array}{l}529 \\
245 \\
\end{array}$ & $\begin{array}{l}68,3 \\
31,7 \\
\end{array}$ \\
\hline $\begin{array}{l}\text { Hastanede kalma süresi } \\
2-5 \text { gün } \\
6-11 \text { gün } \\
12-16 \text { gün } \\
17-21 \text { gün } \\
22 \text { gün ve üzeri }\end{array}$ & $\begin{array}{r}432 \\
197 \\
76 \\
20 \\
49 \\
\end{array}$ & $\begin{array}{r}55,8 \\
25,5 \\
9,8 \\
2,6 \\
6,3 \\
\end{array}$ \\
\hline $\begin{array}{l}\text { Ek hastalık varlığı } \\
\text { Var } \\
\text { Yok }\end{array}$ & $\begin{array}{l}345 \\
429 \\
\end{array}$ & $\begin{array}{l}44,6 \\
55,4\end{array}$ \\
\hline $\begin{array}{l}\text { Bilgi alma durumu } \\
\text { Evet } \\
\text { Hayır }\end{array}$ & $\begin{array}{l}653 \\
121\end{array}$ & $\begin{array}{l}84,4 \\
15,6\end{array}$ \\
\hline $\begin{array}{l}\text { Bilgi alınan kişi }(\mathbf{n}=\mathbf{6 5 3}) \\
\text { Hemşire } \\
\text { Hekim } \\
\text { Hemşire+Hekim }\end{array}$ & $\begin{array}{l}158 \\
348 \\
147\end{array}$ & $\begin{array}{l}20,4 \\
45,0 \\
19,0\end{array}$ \\
\hline $\begin{array}{l}\text { İletişim kurabilme durumu } \\
\text { Evet } \\
\text { Hayır }\end{array}$ & $\begin{array}{c}707 \\
67\end{array}$ & $\begin{array}{c}91,3 \\
8,7\end{array}$ \\
\hline $\begin{array}{l}\text { Aile ya da arkadaşlarından destek alma durumu } \\
\text { Evet } \\
\text { Hayır }\end{array}$ & $\begin{array}{c}736 \\
38\end{array}$ & $\begin{array}{c}95,1 \\
4,9\end{array}$ \\
\hline $\begin{array}{l}\text { Gereksinimlerinin karşılanma durumu } \\
\text { Evet } \\
\text { Hayır }\end{array}$ & $\begin{array}{c}686 \\
88 \\
\end{array}$ & $\begin{array}{l}88,6 \\
11,4\end{array}$ \\
\hline $\begin{array}{l}\text { Hemşirelik bakımından memnun olma durumu } \\
\text { Evet } \\
\text { Hayır }\end{array}$ & $\begin{array}{c}710 \\
64\end{array}$ & $\begin{array}{r}91,7 \\
8,3\end{array}$ \\
\hline
\end{tabular}


ne/klinik, hastanede yatma ve ameliyat olma deneyimi, kanser tanısı alma durumu, ameliyat öncesi /sonrası dönem, sağlık personeli ile iletişim kurabilme, hastalığ alma ve gereksinimlerinin karşılanması durumu ile anksiyete ve depresyon düzeyi puan ortalamaları arasında istatistiksel olarak anlamlı fark olma$\mathrm{d}_{1} \breve{g ̆}_{1}$ saptand 1 ( $\left.\mathrm{p}>0.05\right)$.

Yetmiş üç ve üzeri yaş grubu hastaların anksiyete ve depresyon düzeyi puan ortalaması diğer yaş gruplarına göre daha yüksek olarak belirlendi. Hastaların yaş grupları ile depresyon düzeyi puan ortalaması arasında istatistiksel olarak anlamlı fark olmasina rağmen, anksiyete düzeyi puan ortalaması arasındaki fark istatistiksel olarak anlamlı bulunmadı (Tablo 2).

Hastaların cinsiyetleri ile anksiyete düzeyleri arasındaki fark istatistiksel olarak anlamlı bulunmasına karşın, depresyon düzeyleri arasındaki fark anlamlı bulunmadı. Kadınların anksiyete düzeyi puan ortalamaları erkeklere göre daha yüksek bulundu (Tablo 2).

Hastaların öğrenim durumlarına göre anksiyete ve depresyon düzeyi puan ortalamaları incelendiğinde, okur-yazar olmayanların puan ortalamalarının diğer hastalardan daha yüksek olduğu görüldü. Hastaların öğrenim durumları ile depresyon puan ortalamaları arasında istatistiksel olarak anlamlı fark olmasına rağmen, anksiyete puan ortalaması arasındaki fark anlamlı değildi. Okur-yazar olmayan hastaların anksiyete ve depresyon düzeyleri daha yüksek bulundu (Tablo 2).

Ev hanımı olan hastaların hem anksiyete, hem depresyon düzeyi puan ortalamaları daha yüksek olmasına rağmen sadece anksiyete düzeyi puan ortalamaları arasındaki fark istatistiksel olarak anlam11 bulundu. Sosyal güvencesi olmayan ve ekonomik durumu kötü olan hastaların anksiyete ve depresyon düzeyleri daha yüksekti. Aradaki fark istatistiksel olarak anlamlı idi (Tablo 2).

Hastanede uzun süre (22 gün ve üzeri) kalan hastaların anksiyete ve depresyon düzeyi puan ortalamaları daha yüksek olmasına rağmen, sadece depresyon düzeyi arasındaki fark istatistiksel olarak anlamlı olarak tespit edildi. Ayrıca ek hastalığı olan hastaların anksiyete ve depresyon düzeylerinin daha yüksek olduğu belirlendi ve anksiyete ile depresyon düzeyleri arasındaki fark istatistiksel açıdan anlamlı bulundu (Tablo 2).

Kanser tanısı alan hastaların anksiyete ve depresyon düzeyi puan ortalamalarının diğer hastalara göre daha yüksek olmasına rağmen aradaki farkın istatistiksel olarak anlamlı olmadı̆̆

Hastalığı hakkında bilgi alan ve almayan hastalar arasında istatistiksel olarak anlamlı bir fark olmamasına rağmen; bilgi alanların anksiyete düzeyi, almayanların ise depresyon düzeyi puan ortalaması daha yüksek bulundu. Ayrıca hemşirelik bakımından memnun olmayan hastaların anksiyete ve depresyon düzeyi puan ortalamalarının daha yüksek olduğu belirlendi. İstatistiksel açıdan ise sadece anksiyete düzeyi puan ortalamaları arasındaki fark anlamlı bulundu (Tablo 2).

\section{TARTIŞMA}

Bu çalışmada hastalar genel olarak değerlendirildiğinde ( $\mathrm{n}=774)$ HAD-anksiyete puan ortalaması 7,96 $\pm 4,2$, HAD-depresyon puan ortalamas1 7,95 $\pm 4,47$ olarak bulundu. Hastaların anksiyete puan ortalaması ölçek kesme puanının altında, depresyon puan ortalaması ise ölçek kesme puanının üstündedir. Genel olarak hastaların depresyon bozukluğu açısından risk altında olduğu düşünülebilir.

Hastaların medeni durumları ile anksiyete ve depresyon düzeyi puan ortalamaları arasında istatistiksel olarak anlamlı fark olmadığ saptandı. Literatürde bu çalışma bulgularına benzelik gösteren sonuçlar olmasına rağmen $(4,15,16)$ evlilerde ameliyat öncesi anksiyete oranının bekarlara göre daha yüksek olduğunu belirten çalışmalar da mevcuttur (17). Literatür bilgilerine paralel olarak bu çalışmada da anksiyete ve depresyon düzeyi puan ortalamaları ile ameliyat olma deneyimi arasındaki fark istatistiksel olarak anlamlı bulunmadı (15). Diğer bir çalışmada, önceden cerrahi geçirenlerde ameliyat öncesi anksiyete oranının geçirmeyenlere göre daha yüksek olarak bulunduğu bildirilmektedir (17).

Destek aldığını ve almadığını ifade eden hastaların anksiyete ve depresyon düzeyi puan ortalamaları arasinda istatistiksel olarak anlamlı fark olmadığ 1 saptandi. Literatürde ise sosyal desteği güçlü olan hastaların, 
Tablo 2. Hastaların Tanıtıcı Özelliklerine Göre Anksiyete ve Depresyon Düzeyi Puan Ortalamalarının Dağılımı (n=774)

\begin{tabular}{|c|c|c|c|c|c|}
\hline Tanıtıcı Özellikler & Sayı & HAD-A X \pm SS & Önemlilik & HAD-D X $\pm S S$ & Önemlilik \\
\hline $\begin{array}{l}\text { Yaş grupları } \\
18-28 \text { yaş } \\
29-39 \text { yaş } \\
40-50 \text { yaş } \\
51-61 \text { yaş } \\
62-72 \text { yaş } \\
73 \text { yaş ve üzeri }\end{array}$ & $\begin{array}{c}81 \\
84 \\
140 \\
141 \\
193 \\
135 \\
\end{array}$ & $\begin{array}{l}7,18 \pm 4,35 \\
8,08 \pm 3,71 \\
7,87 \pm 3,92 \\
7,88 \pm 4,30 \\
7,79 \pm 4,60 \\
\mathbf{8 , 7 7 \pm 4 , 3 1}\end{array}$ & $\begin{array}{l}F=1.618 \\
p=0.153\end{array}$ & $\begin{array}{l}6,62 \pm 4,16 \\
7,67 \pm 4,41 \\
7,68 \pm 4,33 \\
7,26 \pm 4,12 \\
8,22 \pm 4,47 \\
\mathbf{9 , 5 5} \pm \mathbf{4 , 7 5}\end{array}$ & $\begin{array}{c}F=6,051 \\
\mathbf{p}=\mathbf{0 , 0 0}\end{array}$ \\
\hline $\begin{array}{l}\text { Cinsiyet } \\
\text { Kadin } \\
\text { Erkek }\end{array}$ & $\begin{array}{l}355 \\
419 \\
\end{array}$ & $\begin{array}{c}8,38 \pm 4,43 \\
7,613 \pm 4,10\end{array}$ & $\begin{array}{c}\mathbf{p}=\mathbf{0 , 0 1 2} \\
\mathrm{t}=2,507\end{array}$ & $\begin{array}{l}7,94 \pm 4,58 \\
7,95 \pm 4,47 \\
\end{array}$ & $\begin{array}{c}\mathrm{p}=0,938 \\
\mathrm{t}=-, 078\end{array}$ \\
\hline $\begin{array}{l}\text { Öğrenim durumu } \\
\text { Okur-yazar değil } \\
\text { Okur-yazar } \\
\text { İlköğretim } \\
\text { Ortaöğretim } \\
\text { Lise } \\
\text { Yüksekokul }\end{array}$ & $\begin{array}{c}22 \\
85 \\
389 \\
93 \\
109 \\
76 \\
\end{array}$ & $\begin{array}{l}\mathbf{9 , 9 0 \pm 4 , 8 0} \\
8,03 \pm 4,65 \\
8,09 \pm 4,22 \\
7,64 \pm 4,36 \\
7,53 \pm 3,84 \\
7,34 \pm 4,30 \\
\end{array}$ & $\begin{array}{c}\mathrm{KW}=8,608 \\
\mathrm{p}=0,126\end{array}$ & $\begin{array}{c}\mathbf{1 1 , 3 1 \pm 5 , 0 0} \\
9,09 \pm 4,84 \\
7,83 \pm 4,22 \\
8,16 \pm 4,26 \\
7,55 \pm 4,58 \\
6,67 \pm 4,57\end{array}$ & $\begin{array}{c}\mathrm{KW}=22,646 \\
\mathbf{p}=\mathbf{0 , 0 0 0}\end{array}$ \\
\hline $\begin{array}{l}\text { Mesleği } \\
\text { Ev hanımı } \\
\text { İşçi } \\
\text { Emekli } \\
\text { Memur } \\
\text { Öğrenci } \\
\text { Serbest } \\
\text { Çiftçi }\end{array}$ & $\begin{array}{c}273 \\
141 \\
193 \\
51 \\
25 \\
57 \\
34\end{array}$ & $\begin{array}{l}\mathbf{8 , 6 1} \pm 4,44 \\
8,08 \pm 3,92 \\
7,52 \pm 4,61 \\
7,15 \pm 3,82 \\
7,36 \pm 5,54 \\
7,29 \pm 4,01 \\
7,55 \pm 4,42 \\
\end{array}$ & $\begin{array}{c}\mathrm{KW}=14,564 \\
\mathbf{p}=\mathbf{0 , 0 2 4}\end{array}$ & $\begin{array}{l}8,21 \pm 4,46 \\
8,31 \pm 4,25 \\
8,21 \pm 4,65 \\
6,50 \pm 4,21 \\
7,12 \pm 4,96 \\
7,08 \pm 4,37 \\
7,14 \pm 4,14 \\
\end{array}$ & $\begin{aligned} \mathrm{KW} & =11,932 \\
\mathrm{p} & =0,06\end{aligned}$ \\
\hline $\begin{array}{l}\text { Sağlık güvencesi olma durumu } \\
\text { Var } \\
\text { Yok }\end{array}$ & $\begin{array}{c}726 \\
48 \\
\end{array}$ & $\begin{array}{l}7,88 \pm 4,30 \\
9,18 \pm 3,49 \\
\end{array}$ & $\begin{array}{l}t=-2,458 \\
p=0,017\end{array}$ & $\begin{array}{l}7,84 \pm 4,48 \\
9,20 \pm 4,09 \\
\end{array}$ & $\begin{array}{l}t=-2,170 \\
p=0,034\end{array}$ \\
\hline $\begin{array}{l}\text { Ekonomik durum } \\
\text { İyi } \\
\text { Orta } \\
\text { Kötü }\end{array}$ & $\begin{array}{c}86 \\
594 \\
94 \\
\end{array}$ & $\begin{array}{l}7,12 \pm 4,75 \\
7,89 \pm 4,13 \\
9,15 \pm 4,45\end{array}$ & $\begin{array}{l}F=5,463 \\
p=0,004\end{array}$ & $\begin{array}{l}6,54 \pm 4,71 \\
7,98 \pm 4,43 \\
9,09 \pm 4,14\end{array}$ & $\begin{array}{l}F=7,453 \\
p=0,001\end{array}$ \\
\hline $\begin{array}{l}\text { Hastanede kalma süresi } \\
2-5 \text { gün } \\
6-11 \text { gün } \\
12-16 \text { gün } \\
\text { 17-21 gün } \\
22 \text { gün ve üzeri }\end{array}$ & $\begin{array}{c}432 \\
197 \\
76 \\
20 \\
49\end{array}$ & $\begin{array}{l}7,71 \pm 4,34 \\
8,08 \pm 4,06 \\
8,18 \pm 4,36 \\
8,40 \pm 3,89 \\
\mathbf{9 , 2 0 \pm 4 , 2 5}\end{array}$ & $\begin{array}{c}\mathrm{KW}=6,092 \\
\mathrm{p}=0,192\end{array}$ & $\begin{array}{c}7,44 \pm 4,26 \\
8,27 \pm 4,41 \\
8,50 \pm 4,72 \\
8,65 \pm 3,78 \\
\mathbf{1 0 , 0 8} \pm \mathbf{5 , 5 1}\end{array}$ & $\begin{array}{c}\mathrm{KW}=14,835 \\
\mathbf{p}=\mathbf{0 , 0 0 5}\end{array}$ \\
\hline $\begin{array}{l}\text { Ek hastalık varlığı } \\
\text { Var } \\
\text { Yok }\end{array}$ & $\begin{array}{l}345 \\
429 \\
\end{array}$ & $\begin{array}{l}\mathbf{8 , 3 3} \pm 4,25 \\
7,66 \pm 4,26 \\
\end{array}$ & $\begin{array}{l}t=2,183 \\
p=0,029\end{array}$ & $\begin{array}{l}\mathbf{8 , 3 2 \pm 4 , 4 8} \\
7,65 \pm 4,44 \\
\end{array}$ & $\begin{array}{l}t=2,069 \\
p=0,039\end{array}$ \\
\hline $\begin{array}{l}\text { Tanı } \\
\text { Kanser cerrahisi } \\
\text { Kanser dışı cerrahi }\end{array}$ & $\begin{array}{l}109 \\
774 \\
\end{array}$ & $\begin{array}{l}\mathbf{8 , 0 0 \pm 4 , 5 2} \\
7,96 \pm 4,27\end{array}$ & $\begin{array}{l}\mathrm{p}=0.929 \\
\mathrm{t}=0,089\end{array}$ & $\begin{array}{l}\mathbf{8 , 2 4} \pm \mathbf{4 , 4 8} \\
7,90 \pm 4,47\end{array}$ & $\begin{array}{l}\mathrm{p}=0.465 \\
\mathrm{t}=0,731\end{array}$ \\
\hline $\begin{array}{l}\text { Bilgi Alma Durumu - Alan/Almayan } \\
\text { Evet } \\
\text { Hayır }\end{array}$ & $\begin{array}{l}653 \\
121\end{array}$ & $\begin{array}{c}\mathbf{8 , 0 5} \pm \mathbf{4}, \mathbf{2 0} \\
7.51 \pm 4,60 \\
\end{array}$ & $\begin{array}{l}p=0.203 \\
t=1.274\end{array}$ & $\begin{array}{l}7,93 \pm 4,40 \\
\mathbf{8 , 0 7 \pm 4 , 8 3}\end{array}$ & $\begin{array}{c}\mathrm{p}=0.754 \\
\mathrm{t}=-, 313\end{array}$ \\
\hline $\begin{array}{l}\text { Hemşirelik bakımından memnun olma } \\
\text { Evet } \\
\text { Hayır }\end{array}$ & $\begin{array}{c}710 \\
64 \\
\end{array}$ & $\begin{array}{l}7,96 \pm 4,28 \\
8,03 \pm 4,13 \\
\end{array}$ & $\begin{array}{l}t=-, 127 \\
p=0,899\end{array}$ & $\begin{array}{l}7,84 \pm 4,41 \\
9,20 \pm 4,92 \\
\end{array}$ & $\begin{array}{l}\mathrm{t}=-2,333 \\
\mathrm{p}=0,020\end{array}$ \\
\hline
\end{tabular}

ameliyat öncesi anksiyete düzeylerinin daha düşük olduğu belirtilmektedir (17). Cerrahi hastaların incelendiği diğer bir çalışmada benzer şekilde ailesel desteği düşük olan hastaların, destek sistemleri daha iyi olan hastalara göre anksiyete ve depresyon açısından risk altında oldukları vurgulanmaktadır (5).

Çalışma bulgularına göre; yetmiş üç yaş ve üzeri hastalaların anksiyete ve depresyon düzeyi puan ortalaması diğer yaş gruplarına göre daha yüksek olarak belirlendi. Hastaların yaş grupları ile depresyon dü- 
zeyi puan ortalaması arasında istatistiksel olarak anlamlı fark olmasına rağmen anksiyete düzeyi puan ortalaması arasındaki fark istattistiksel olarak anlamlı bulunmadı (Tablo 2). Literatürde de bu çalışma bulgularına benzer şekilde 60 yaş üstü hastaların tamamının depresyonda olduğu ve \%75'inde anksiyete bulgularının gözlemlendiği belirtilmektedir (18). Konuyla ilgili yapılan farklı çalışmalarda aynı şekilde 65 yaş ve üzerindeki hastalarda depresyon görülme oranları diğer yaş gruplarındaki hastalara göre daha yüksek olduğu (4), 60 yaş ve üzerindeki hastalarda ameliyat öncesi anksiyete oranının diğer yaş gruplarına göre daha yüksek olduğu bildirilmektedir (17).

Cerrahi hastalarda anksiyete ve depresyon düzeylerinin incelendiği bir başka çalışmada 35 yaş ve üstü olan hastaların anksiyete puanlarının daha yüksek ve aradaki farkın istatistiksel olarak anlamlı olduğu bildirilmektedir (3). Cerrahi hastaları ile yapılan farklı çalışmalarda ise hastaların yaşı ile anksiyete ve depresyon görülme düzeyleri arasında istatistiksel olarak anlamlı ilişkinin olmadığı belirtilmektedir $(15,16)$. Benzer şekilde kalp damar cerrahisi hastaları ile yapılan bir diğer çalışmada da yaş grupları ile anksiyete ve depresyon belirtileri arasında istatistiksel olarak anlamlı fark bulunmadığı ortaya konulmaktadır (19).

Hastaların cinsiyetlerine göre anksiyete düzeyleri arasındaki fark çalışmamızda istatistiksel olarak anlamlı olmasına rağmen, depresyon düzeyleri arasindaki fark anlamlı bulunmadı. Kadınların anksiyete düzeyi puan ortalamalarının erkeklere göre daha yüksek olduğu belirlendi (Tablo 2). Literatürde cerrahi kliniklerde yatan hastaların dahil edildiği bir çalışmada bizim çalışmamıza benzer şekilde şiddetli anksiyete görülme oranı kadınlarda \%68,5 iken erkeklerde \%53,3 olarak belirlenmiştir. Yine aynı çalışmada kadın hastalarda depresyon görülme oranlarının da erkeklerden daha fazla olduğu belirtilmektedir (18). Bir başka çalışmada da hastalarda anksiyete ve depresyon düzeylerine bakılmış, depresyon düzeyleri kadın ve erkek hastalarda farklılık göstermezken anksiyete düzeyleri kadınlarda $(\% 45,5)$ erkeklere $(\% 30,6)$ göre daha yüksek düzeyde belirlenmiştir (4). Kalp damar cerrahisi hastalarında anksiyete ve depresyon düzeylerinin incelendiği bir çalışmada da; kadınlarda anksiyete ve depresyon düzeyleri ameliyat öncesi dönemde erkeklere göre daha yüksek bulunmuş ve aralarındaki farkın istatistiksel olarak anlamlı olduğu belirtilmiştir (19). Cerrahi hastaların incelendiği bir çalışmada kadınlarda anksiyete ve depresyon oranları erkeklerden daha yüksek bulunmuş $(5,16)$, bir başka çalışmada ise kadın cinsiyet ve yüksek anksiyete puanları arasındaki ilişkinin anlamlı olduğu belirlenmiştir $(3,20)$. Kanser hastalarının dahil edildiği bir başka çalışmada da; kadınlarda anksiyete ve depresyon düzeylerinin daha yüksek olduğu ortaya konulmuştur (21). Tüm bunların yanı sıra cerrahi hastaların incelendiği bir çalışmada; hastaların cinsiyeti ile anksiyete ve depresyon görülme düzeyleri arasında istatistiksel olarak anlamlı ilişkinin olmadığı belirtilmiştir (15). Tüm bunların yanı sıra farklı bir çalışmada erkek hastalarda ameliyat öncesi anksiyete görülme oranı kadın hastalardan daha yüksek bulunmuştur (17).

Hastaların öğrenim düzeylerine göre anksiyete ve depresyon düzeyi puan ortalamaları incelendiğinde çalışmamızda okur-yazar olmayan hastaların puan ortalamalarının diğer hastalardan daha yüksek olduğu görüldü. Hastaların öğrenim durumları ile depresyon puan ortalamaları arasında istatistiksel olarak anlamlı fark olmasına rağmen, anksiyete puan ortalaması arasındaki fark anlamlı değildir. Okur-yazar olmayan hastaların anksiyete ve depresyon düzeyleri daha yüksektir (Tablo 2). Literatürde de hastaların öğrenim durumları ile anksiyete ve depresyon düzeylerinin karşılaştırılması ile ilgili yapılan bir çalışmada bu çalışma sonuçlarına benzer şekilde okur-yazar olmayan hastaların anksiyete ve depresyon düzeylerinin üniversite mezunu olan hastalara göre daha yüksek olarak tespit edildiği bildirilmektedir (4). Cerrahi hastaların incelendiği bir başka çalışmada da okur-yazar olmayanların anksiyete ve depresyon puan ortalamalarının diğer gruplardan daha yüksek olduğu vurgulanmakta, hastaların eğitim durumları ile anksiyete ve depresyon puan ortalamaları arasında istatistiksel olarak anlamlı fark olmadığ konulmaktadır (16). Konuyla ilgili yapılan diğer çalışmalarda da eğitim seviyesi düşük olan hastalarda diğer gruplara göre anksiyete ve depresyon oranları- 
nın daha yüksek olduğu belirtilmekte, düşük eğitim düzeyi ile yüksek anksiyete ve depresyon puanları arasındaki ilişkinin anlamlı olduğu vurgulanmakta$\operatorname{dir}(3,5,15,17,22)$.

Çalışmamızda ev hanımı olan hastaların hem anksiyete hem de depresyon düzeyi puan ortalamaları daha yüksek olmasına rağmen sadece anksiyete düzeyi puan ortalamaları arasındaki fark istatistiksel olarak anlamlı bulundu. Cerrahi hastaların incelendiği bir başka çalışmada da ev hanımı olan hastaların anksiyete ve depresyon puanlarının diğer hastalardan daha yüksek olarak bulunduğu bildirilmektedir (16). Tüm bunların yanı sıra bir başka çalışmada ise anksiyete ve depresyon görülme düzeyleri ile hastaların meslekleri arasında anlamlı ilişkinin olmadığı belirtilmektedir $(4,15)$.

Sosyal güvencesi olmayan ve ekonomik durumu kötü olan hastaların anksiyete ve depresyon düzeyleri çalışmamızda daha yüksek bulundu ve aradaki farkın istatistiksel olarak anlamlı olduğu belirlendi (Tablo 2). Cerrahi hastalarda anksiyete ve depresyon düzeylerinin incelendiği bir çalışmada da düşük sosyoekonomik düzey ile yüksek anksiyete puanları arasındaki ilişkinin anlamlı olduğu ve düşük gelirli grupta anksiyete düzeyinin daha yüksek olduğu belirtilmektedir (3). Depresyon oranlarının ve risk faktörlerinin incelendiği bir başka çalışmada ise ekonomik düzeyi düşük bireylerde depresyon oranlarının daha yüksek olduğu vurgulanmaktadır (22). Benzer şekilde bir başka çalışmada da sosyal desteği az olan ve düşük gelire sahip bireylerde anksiyete oranlarının daha yüksek olduğu bildirilmektedir (20).

Çalışma bulgularına göre hastanede uzun süre (22 gün ve üzeri) kalan hastaların anksiyete ve depresyon düzeyi puan ortalamaları daha yüksek olmasına rağmen, sadece depresyon düzeyi arasındaki fark istatistiksel olarak anlamlı bulundu. Literatürde de 3 haftave üzerinde hastanede kalan cerrahi hastalarda anksiyete ve depresyon düzeylerinin diğer hastalara göre daha yüksek olarak bulunduğu ifade edilmektedir (18). Cerrahi hastalarda anksiyete ve depresyon düzeylerinin incelendiği diğer çalışmalarda da, depresyon düzeylerinin hastanede kalış süresi uzadıkça arttığı belirtilmekte (5), hastanede kalış süresinin uzunluğu ile yüksek depres- yon puanları arasındaki ilişkinin anlamlı olduğu vurgulanmaktadır $(3,15)$.

Çalışma bulgularımıza göre ek hastalığı olan hastaların anksiyete ve depresyon düzeylerinin daha yüksek olduğu ve aradaki farkın istatistiksel açıdan anlamlı olduğu tespit edildi (Tablo 2). Benzer şekilde literatürde de kronik hastalığı olan hastalarda olmayanlara göre ameliyat öncesi anksiyete oranının daha yüksek olduğu belirtilmektedir (17). Ayrıca uzun süreli hastalık öyküsü olan hastalarda anksiyete görülme düzeylerinin daha yüksek olduğu vurgulanmaktadır (4). Depresyon oranlarının ve risk faktörlerinin incelendiği bir başka çalışmada da kronik hastalığı olan bireylerde depresyon oranlarının daha yüksek olduğu ifade edilmektedir (22).

Kanser tanısı alan hastaların anksiyete ve depresyon düzeyi puan ortalamalarının diğer hastalara göre daha yüksek olmasına rağmen aradaki farkın istatistiksel olarak anlamlı olmadığı tespit edildi. Kanser hastaları ile diğer hasta gruplarının anksiyete ve depresyon düzeylerinin karşılaştırıldığı bir çalışmada, kanser hastalarında diğer popülasyona kıyasla anksiyete ve depresyon düzeylerinin yaklaşık iki katı daha yüksek olduğu belirtilmektedir (23). Konuyla ilgili yapılan bir başka çalışmada da cerrahi kliniğinde yatan kanser tanısı konulmuş hastalarda anksiyete ve depresyon seviyesinin bu tanının konulmadığı hastalara göre daha yüksek olduğu ortaya konulmaktadır $(3,15)$. Kanser teşhisi sonras1 anksiyete ve depresyonun değerlendirildiği bir başka çalışmada ise, kanser teşhisinin konulduğu sürecin anksiyete ve depresyon açısından en riskli zaman olduğu vurgulanmaktadır (21). Bir başka çalışmada da normal popülasyonla kıyaslandığında kanserli hastalarda depresyon düzeyinin daha yüksek olduğu belirtilmektedir (24).

\section{SONUÇ}

Sonuç olarak; İleri yaş grubunda olan, okur-yazar olmayan, hastanede uzun süre kalan, kronik hastal1ğ1 olan, hemşirelik bakımından memnun olmayan, ekonomik durumu kötü olan ve sosyal güvencesi olmayan hastaların hem anksiyete düzeyleri, hem de depresyon düzeyleri daha yüksek olarak belirlenmiş- 
tir. Ev hanımlarının anksiyete düzeyleri işçilerin ise depresyon düzeyleri daha yüksektir. Ayrıca bu çalışmada hastaların anksiyete puan ortalaması ölçek kesme puanının altında, depresyon puan ortalaması ise ölçek kesme puanının üstündedir. Genel olarak cerrahi hastaların depresyon açısından risk altında olduğu düşünülebilir.

$\mathrm{Bu}$ nedenle risk grubunda olan hastaların hekim, hemşire, psikolog ve sosyal hizmet uzmanlarından oluşan profesyonel bir ekip tarafından psikososyal açdan desteklenmesi ve özellikle hastalarla bire bir ilişki içinde olan hemşirelerin bu konuda duyarlı olmaları için bilgilendirilmeleri önerilebilir. Hastalarda anksiyete ve depresyon seviyeleri ve ilişkili faktörlerin belirlenmesi ile, bireylerin tedaviye uyumunun kolaylaşacağı ve yaşam kalitelerinin artıracağı düşünülmektedir.

Hakem Değerlendirmesi: Dış bağımsız.

Peer Review: Externally peer-reviewed.

Etik Komite Onayı: Bu çalışma için etik komite onayı Pamukkale Üniversitesi Tip Fakültesi Etik Kurulu'ndan alınmıştır. (tarih 12.02.2015 ve no 60116787-020/8537)

Ethics Committee Approval: This study was approved by the Ethical Committee of the Pamukkale University Faculty of Medicine. (date 12.02.2015 and number 60116787-020/8537)

Bilgilendirilmiş Onam: Katılımcılardan bilgilendirilmiş onam alınmıştır.

Informed Consent: Written consent was obtained from the participants.

Yazar Katkıları: Çalışma Konsepti/TasarımF.K.H., F.G.; Veri Toplama- F.K.H., F.G.; Veri Analizi/ Yorumlama- F.K.H., F.G.; Yazı Taslağ1- F.K.H., F.G.; İçeriğin Eleştirel İncelemesi- F.K.H., F.G.; Son Onay ve Sorumluluk- F.K.H., F.G.; Malzeme ve Teknik Destek- F.K.H., F.G.; Süpervizyon- F.K.H., F.G.

Author Contributions: Conception/Design of Study- F.K.H., F.G.; Data Acquisition- F.K.H., F.G.; Data Analysis/Interpretation- F.K.H., F.G.; Drafting Manuscript- F.K.H., F.G.; Critical Revision of Manuscript- F.K.H., F.G.; Final Approval and Accountability- F.K.H., F.G.; Technical or Material SupportF.K.H., F.G.; Supervision- F.K.H., F.G.
Çıkar Çatışması: Yazarlar çıkar çatışması beyan etmemişlerdir

Conflict of Interest: Authors declared no conflict of interest.

Finansal Destek: Yazarlar finansal destek beyan etmemişlerdir.

Financial Disclosure: Authors declared no financial support.

\section{KAYNAKLAR/REFERENCES}

1. Oflaz F, Varol H. Yatan hastaların anksiyete ve depresyon düzeyleri ve ilişkili faktörlerin incelenmesi. SDÜ Tip Fak Derg 2010;17:1-7.

2. Kutlu R, Özberk D.I, Gök H, Demirbaş N. Kardiyoloji yoğun bakım ünitesinde yatan hastalarda anksiyete ve depresyon sıklığı ve etki eden faktörler. tgkdc.dergisi 2016;24:672-679.

3. Basak F, Hasbahceci M, Guner S, Sisik A, Acar A, Yucel M, et al. Prediction of anxiety and depression in general surgery inpatients: a prospective cohort study of 200 consecutive patients. Int J Surg 2015;23(Pt A):18-22.

4. Esteghamat S.S, Moghaddami S, Esteghamat S.S, Kazemi H, Kolivand P.H, Gorji A. The course of anxiety and depression in surgical and nonsurgical patients. Int J Psychiatry Clin Pract 2014;18(1):16-20.

5. Shoar S, Naderan M, Aghajani M, SahimiIzadian E, Hosseini-Araghi N, Khorgami Z. Prevalence and determinants of depression and anxiety symptoms in surgical patients. Oman Med J 2016;31(3):176-81.

6. Karayağız F, Altuntaş M, Güçlü Y.A, Yılmazer TT, Öngel K. Cerrahi servisinde yatan hastalarda görülen anksiyete dağılımı. Smyrna Tip Dergisi 2011;1:22-6.

7. Bailey L. Strategies for decreasing patient anxiety in the perioperative setting. AORN Journal 2010;92(4):445-460.

8. Palazón JH, García DF, Araña LF, et al. Assessment of reoperative anxiety in cardiac surgery patients lacking a history of anxiety: contributing factors and postoperative morbidity. J Cardiothorac Vasc Anesth 2018;32(1):236-44. 
9. Cevik B. The evaluation of anxiety levels and determinant factors in preoperative patients. Int J Med Res Health Sci 2018;7(1):135-43. ISSN No: 2319-5886

10. Dayılar H, Oyur G, Kamer E, Sarıçiçek A, Cengiz F, Hacıyanlı M. Kolon ameliyatı öncesi hastaların anksiyete düzeylerinin değerlendirilmesi. Turk J Colorectal Dis 2017;27(1):6-10.

11. Taşdemir A, Erakgün A, Deniz MN, Çertuğ A. Preoperatifbilgilendirmeyapılanhastalardaameliyat öncesi ve sonrası anksiyete düzeylerinin State-Trait Anxiety Inventory Test ile karşılaştırılması. Turk J Anaesth Reanim 2013;41(2):44-9.

12. Çalışkan E, Gürhan N, Tekgündüz AİE. Hematolojik kanserli hastaların anksiyete, depresyon ve distres yaşama durumları. Acta Oncol Tur 2017;50(3):207-17.

13. Zigmond AS, Snaith RP. The hospital anxiety and depression scale. Acta Psychiatr Scand. 1983;67(6):361-70.

14. Aydemir Ö, Güvenir T, Kuey L. Hastane anksiyete ve depresyon ölçeği Türkçe formunun geçerlilik ve güvenilirliği. Türk Psikiyatri Dergisi 1997;8(4):280-7.

15. Santos MMB, Martins JCA. Oliveira L.M.N. Anxiety, depression and stress in the preoperative surgical patient. Revista de Enfermagem Referência 2014;4:7-15.

16. Okanlı A, Özer N, Akyıl RÇ, Koçkar Ç. Cerrahi kliniklerinde yatan hastaların anksiyete ve depresyon düzeylerinin belirlenmesi, Atatürk Üniversitesi Hemşirelik Yüksekokulu Dergisi 2006; 9 (4): 38-44.

17. Bedaso A, Ayalew M. Preoperative anxiety among adult patients undergoing elective surgery: a prospective survey at a general hospital in Ethiopia. Patient Safety in Surgery 2019;13:1-8.

18. Mirani SH, Areja D, Gilani SS, Tahir A, Pathan $\mathrm{M}$, Bhatti S. Frequency of depression and anxiety symptoms in surgical hospitalized patients. Cureus 2019;11(2):1-6.

19. Rodrigues HF, Furuya RK, Dantas RAS, Dessotte CAM. Anxiety and depression in cardiac surgery: sex and age range differences. Esc Anna Nery 2016;20(3):1-7.

20. Almeida OP, Draper B, Pirkis J, Snowdon J, Lautenschlager NT, Byrne G, et al. Anxiety, Depression and Comorbid Anxiety and Depression: Risk Factors and Outcome Over Two Years, International Psychogeriatrics, 2012; 24 (10):1622-32.

21. Linden W, Vodermaier A, MacKenzieb R, Greiga D. Anxiety and depression after cancer diagnosis: Prevalence rates by cancer type, gender, and age, J Affect Disord 2012; 141(2-3): 343-51.

22. Yaka E, Keskinoglu P, Ucku R, Yener GG, Tunca Z. Prevalence and risk factors of depression among community dwelling elderly, Archives of Gerontology and Geriatrics 2014;59(1):150-4.

23. Hınz A, Krauss O, Hauss JP, Höckel M, Kortmann RD, Stolzenburg JU, et al. Anxiety and depression in cancer patients compared with the general population. Eur J Cancer Care 2010;19(4):522-9.

24. Hong JS, Tian J. Prevalence of anxiety and depression and their risk factors in Chinese cancer patients. Support Care Cancer 2014;22(2):453-9. doi: 10.1007/s00520-013-1997-y. 